Session 2793

\title{
Understanding How Freshmen Engineering Students Think They Learn
}

\author{
Joni E. Spurlin, Leonhard E. Bernold, Cathy L. Crossland, and \\ Chris M. Anson, Ph.D. \\ North Carolina State University \\ Raleigh, NC 27695
}

\section{Introduction}

The work in this project is founded on an ongoing effort sponsored by the National Science Foundation " which has as its goal the establishment of a thorough understanding of "what freshmen do" when it comes to "college study" and how or whether their behavior changes during the first year. This new research effort, lead by the authors at North Carolina State University, is presently surveying 930 freshmen engineering students who started their college career in August 2002. The main data collection tools include: a) Pittsburgh Freshman Engineering Attitude Survey, b) Learning and Study Skills Inventory (LASSI), c) Learning Type Measure (LTM), and d) bi-weekly questions developed by the authors which students answered throughout their first semester. The Pittsburgh Freshman Engineering Attitude Survey is designed to assess their opinions, feelings, and confidence about engineering and learning engineering. The survey was given again at the end of the first semester to assess any changes. The LASSI and LTM are designed to help students understand and identify the ways they learn. The surveys questions that the students answered throughout the semester were focused on how they were learning, access to faculty and academic services, and changes during the first semester.

One of the key premises of this project is that making them effective learners within the college environment, which is very different to what they are used to, may reduce the $57 \%$ attrition rate of freshman engineering students. Studies have shown that failing engineering freshman don't have lower academic abilities; in fact, some of them have higher IQ's than the average engineering student. ${ }^{1}$ Other studies demonstrate that traditional lecture oriented teaching leads to lower performance, negative attitudes towards engineering, and decreased self-confidence of some of the students. ${ }^{2}$ Hermann ${ }^{3}$ concluded that, although employers need innovative engineers with strong communication and open-ended problem-solving skills, the heavily analytical and rote problem-solving orientation of current engineering curricula does not foster those needed skills. In a positive national context for employment in engineering, there is an urgent need for research to examine the institutional, pedagogical, and personal reasons for students to give up their pursuit of a career in engineering. Our study is investigating this phenomenon in ways that can help to inform and reform undergraduate education in engineering.

${ }^{*}$ Grant funded by National Science Foundation, Division of Engineering Education and Centers, Award \# 0212150

"Proceedings of the 2003 American Society for Engineering Education Annual Conference \& Exposition, Copyright (C) 2003, American Society for Engineering Education" 
This paper describes the preliminary findings from results of the surveys and what engineering students understand about their own learning strategies as they start out. These dimensions indicate that more than half of the students who have started out in engineering learn from straightforward data, logical thinking and problem solving. The disadvantage of being these types of learners is that they have more difficulty relating to the personal dynamics of working with others, working for collaborative solutions, or discussing open-ended problems and are impatient with exploring fuzzy concepts

\section{Methodology}

The first six months of this research effort have focused on the first-year engineering students who started their college careers in mid-August 2002 at North Carolina State University. Of the 1103 new incoming freshmen students who entered NCSU in fall 2002, 1021 agreed to participate in the study. Data were collected on these students using three survey instruments: the Pittsburgh Freshmen Engineering Attitudes Survey (Pittsburgh); the Learning and Study Skills Inventory (LASSI); and the Learning Type Measure (LTM). The literature has shown that these surveys have been validated and are reliable. ${ }^{4,5,6,7}$ In addition, students responded to weekly surveys designed to assess their attitudes toward various aspects of learning, and more openended questions that elicited journal-like written responses. Survey questions asked students to judge statements such as "I am able to figure out for myself how to learn new information and material" on a scale of "rarely," "sometimes," and "usually." These surveys were readministered toward the end of the academic semester, providing an index of change or lack thereof. Open-ended journal questions asked students to elaborate on their experiences and beliefs, e.g., "Describe the instructional setting (large lectures, small groups, labs) with which you experience the most frustration." Each student answered three such journal questions per form, or 27 questions during the semester, yielding a total of approximately 27,000 responses of 50-200 words. In answering the surveys and open-ended questions, the students were asked to think about their entire educational experience of the first semester, and not focus on any one course. The majority of students took a math course, a science course of chemistry or physics, and an English composition course, and all students took an introduction to engineering problem solving course. Thus, their curriculum consisted of basic educational courses that are providing the foundation for engineering courses later in their curriculum. Additional data were gathered such as demographics, previous success in high school, gender and ethnicity, grades in current courses and retention.

Information gathered in this study consists of large amounts of quantitative data and qualitative data. Analysis of quantitative data is correlational, statistically relating various measures using ANOVA, regression, and factor analysis. Journal responses are being analyzed both quantitatively (e.g., mean length of entries in words, mean sentence length, use of specific punctuation, predominance of certain linguistic structures such as conditionals, etc.) and qualitatively (content analysis and error analysis). Additionally, the journal responses of cohorts created from the results of learning style inventories can be examined qualitatively for various patterns of response.

Because the data for the first phase of this study have not yet been collected in full, analysis is ongoing. We report here some of the preliminary results.

\footnotetext{
"Proceedings of the 2003 American Society for Engineering Education Annual Conference \& Exposition, Copyright (C) 2003, American Society for Engineering Education",
} 


\section{Preliminary Analysis of Data}

One of the objectives of the first year of this project was "to develop a basic understanding of the interrelationships among applied learning strategies of engineering freshman and their personal learning preferences, gender, ethnicity, definition of success in college, and the teaching strategies presented in their high school education."

Consistency measures: Preliminary results of correlations between different survey items show that students are responding accurately, consistently, and predictably. For example, there is a statistically significant inverse relationship between responses to the items "I take too many breaks when I am studying" and "The schedule I have developed for studying for each of my courses is effective." This consistency is also demonstrated in relationships between inventories and survey questions; for example, students with higher levels of educational anxiety as measured by the LASSI were more likely to respond "sometimes" or "usually" to the question, "I wonder if I am well prepared for the academic demands of being a university student."

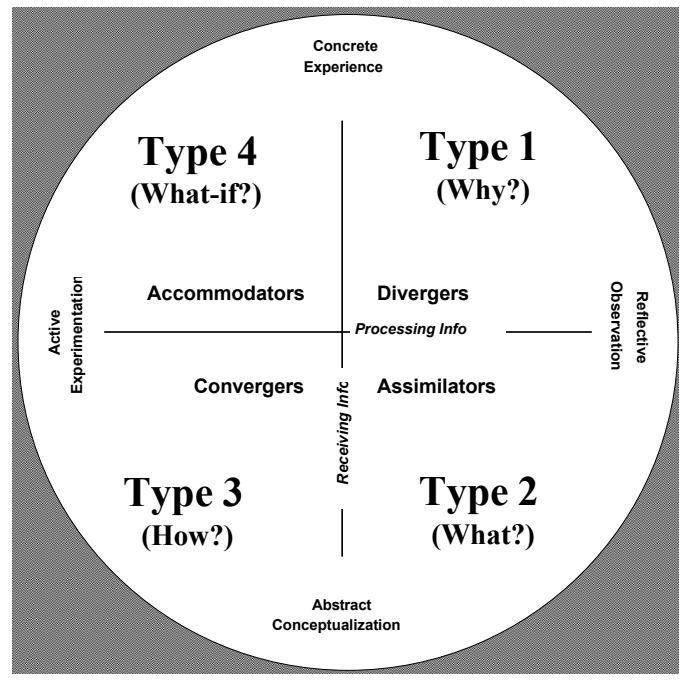

\section{Figure 1: Model of Kolb's 4 Main Learning Styles ${ }^{8}$}

Students who scored highest in one quadrant of the LTM were examined. The LTM gives a score for each of Kolb's four learning styles. A composite picture of each student's learning style is created from the results of the inventories. An index places students into one of four type quadrants using terminology from the LTM: "Why?" learners (1), "What?" learners (2), "How?" learners (3), and "What if?" learners (4). Figure 2 gives the percentage of the participants by each of their strongest LTM subscore. Distributions for ethnicity and gender groups can also be seen. 
Session 2793

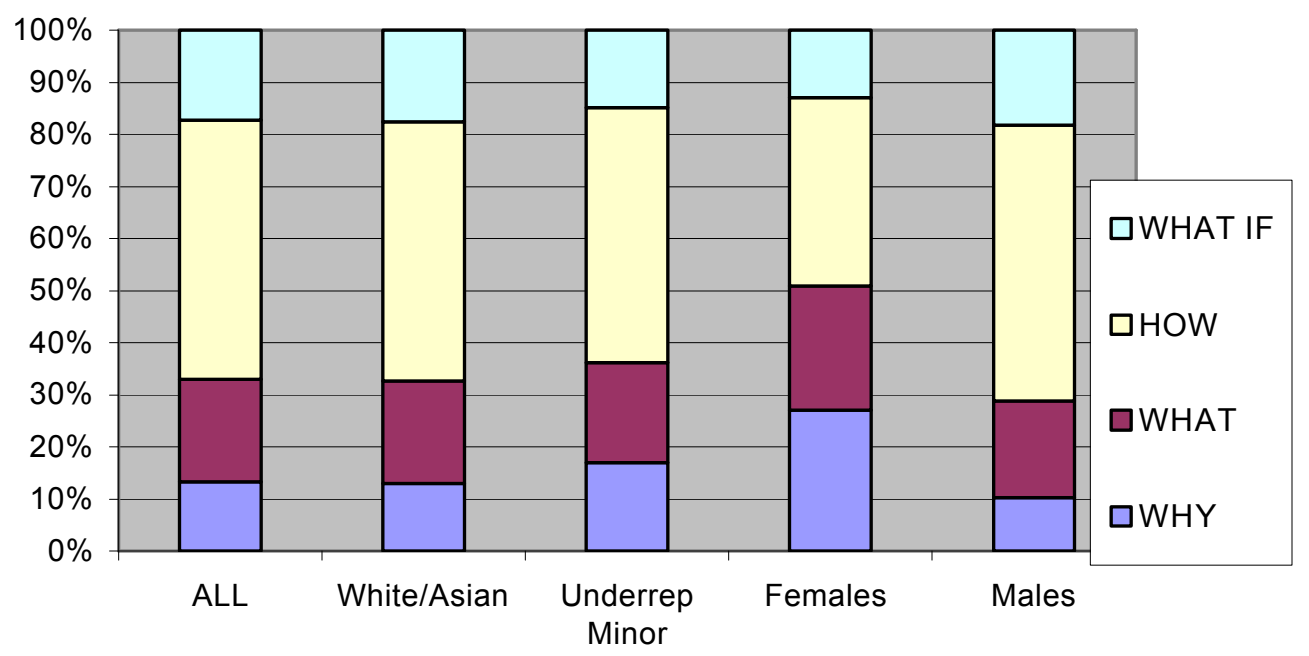

Figure 2. Distribution of LTM 4 Quadrants (All groups calculated to 100\%)

Results show that the largest group in any category is represented by the HOW learners. Examining the way that each ethnic group or gender is represented in each LTM quadrant, it can be seen that more females are "LTM 1 - WHY" than males and more males are "LTM 4 WHAT IF" than females. The underrepresented minority group looks similar to the white/Asian group. In our student population, it is apparent that the majority of students (49\%) prefer Learning Type 3 - HOW. Together with LTM Type 2 - WHAT, they comprise $69 \%$ of the freshmen engineering students. In 1983, an extensive study was performed on eight engineering schools to measure the psychological type effects on the educational and career development of engineering. ${ }^{9}$ The results of the 1983 study showed that the engineering students were almost equally divided between the sensing type (53\%) and the Intuitive type (47\%). More recently, Harb, Terry, Hurt, and Williamson, 1991, ${ }^{10}$ assessed the learning preferences of engineering students at Brigham Young University. The following approximate distribution was found: 10\% Type 1, 40\% Type 2, 30\% Type 3 and 20\% Type 4 . Our results are consistent with those found in these studies.

Using ANOVAs with the independent variable being the highest quadrant on the LTM and the dependent variable being the question on a journal assignment, subscores on LASSI or subscores on Pittsburgh Freshmen Engineering Attitude Survey, the following items had statistically significant ANOVAs. The students in the study were examined by how they scored on the LTM and then how their attitudes on the various surveys correlated with the score on the LTM. The following describes the statistically significant results found by each of the four LTM quadrants. (See the Table 1 for data.)

LTM 1 (WHY?): Students who scored the highest in this quadrant on the LTM were more frustrated by their skills in getting themselves organized to study; questioned their commitment to the engineering field; and felt more concerned about their academic performance. The Pittsburgh Survey (taken in the first week) showed that they had the least confidence in math, science, engineering and computer skills and some confidence in writing and liberal arts studies. These students, compared to students who scored higher on the other LTM quadrants, showed more anxiety on the LASSI subscale; and

"Proceedings of the 2003 American Society for Engineering Education Annual Conference \& Exposition, Copyright (C) 2003, American Society for Engineering Education" 
scored high on the Study Aide subscale of the LASSI that indicated they use more resources to learn.

LTM 2 (WHAT?): Students with this LTM subscore as the highest stated they used textbooks to help them more than students with other LTM subscores; they preferred to study alone and felt grades reflect their abilities. The Pittsburgh Survey corroborated that these students prefer to work alone instead of in groups or teams. They scored high on the Concentration Subscale of LASSI - they have the ability to direct and maintain attention on academic tasks.

LTM 3 (HOW?): Student in this quadrant are very similar to LTM 2 students. They use textbooks to help them more; they did not question if the engineering field was for them and felt grades reflected their abilities.

LTM 4 (WHAT IF?): Compared to the other three groups, LTM 4 students, by midterm, did not feel that the instructors were available outside of class. They were frustrated in their organization at the beginning of the semester and at midterm. They did not feel that homework promoted understanding of the material. By midterm, they had the most trouble getting to class on time than other students who scored higher on other LTM quadrants. They scored low on the Motivation Scale and Time Management scale of the LASSI, e.g., they may not possess the diligence, self-discipline, and willingness to exert the effort necessary to successfully complete academic requirements. They did not think of engineering as a rewarding career.

TABLE 1: Averages on survey items for each LTM subgroup

\begin{tabular}{|c|c|c|c|c|c|}
\hline \multicolumn{6}{|c|}{$\begin{array}{l}\text { Average On Survey Questions Asked During The Semester } \\
\text { Scale: } 1=\text { "rarely"; } 2=\text { "sometimes"; 3= "usually" }\end{array}$} \\
\hline $\begin{array}{c}\text { LTM } \\
\text { Quadrant }\end{array}$ & $\begin{array}{l}\text { Textbooks } \\
\text { Help me }\end{array}$ & $\begin{array}{l}\text { Perfer to } \\
\text { study alone }\end{array}$ & $\begin{array}{l}\text { Instructor is } \\
\text { available } \\
\text { outside of } \\
\text { class } \\
\text { (beginning of } \\
\text { semester) }\end{array}$ & $\begin{array}{l}\text { Instructor is } \\
\text { available } \\
\text { outside of } \\
\text { class (middle } \\
\text { of semester) }\end{array}$ & $\begin{array}{l}\text { Homework } \\
\text { promotes my } \\
\text { understandi } \\
\text { ng of the } \\
\text { material }\end{array}$ \\
\hline $1-\mathrm{WHY}$ & $2.43+++$ & $2.21^{\wedge}$ & 1.20 & 2.60 & 2.50 \\
\hline 2 - WHAT & 2.53 & $2.66^{\wedge}$ & 1.24 & 2.52 & 2.52 \\
\hline 3 - HOW & 2.56 & $2.45^{\wedge}$ & 1.17 & 2.51 & 2.47 \\
\hline $\begin{array}{l}4-\mathrm{WHAT} \\
\mathrm{IF}\end{array}$ & $2.36 \#$ & $2.35^{\wedge}$ & $1.34 \#$ & $2.36^{*} \#$ & $2.29 *$ \\
\hline & & & & & \\
\hline
\end{tabular}

"Proceedings of the 2003 American Society for Engineering Education Annual Conference \& Exposition, Copyright (C) 2003, American Society for Engineering Education"” 


\begin{tabular}{|c|c|c|c|c|c|c|}
\hline & & $\begin{array}{c}\text { Frustrated } \\
\text { by my skills } \\
\text { to get myself } \\
\text { organized to } \\
\text { study } \\
\text { (beginning of } \\
\text { semester) } \\
\end{array}$ & $\begin{array}{c}\text { Frustrated } \\
\text { by my skills } \\
\text { to get myself } \\
\text { organized to } \\
\text { study } \\
\text { (middle of } \\
\text { semester) } \\
\end{array}$ & $\begin{array}{l}\text { I question if } \\
\text { engineering } \\
\text { is right for } \\
\text { me }\end{array}$ & $\begin{array}{c}\text { Grades } \\
\text { reflect } \\
\text { abilities }\end{array}$ & $\begin{array}{c}\text { Concern } \\
\text { about my } \\
\text { performance } \\
\text { in some } \\
\text { courses }\end{array}$ \\
\hline $1-$ & $\mathrm{JHY}$ & $1.89+\#+$ & 1.37 & $1.88 * *$ & $2.14+++$ & $2.30+\#+$ \\
\hline $2-$ & HAT & 1.63 & $1.27^{\wedge \wedge}$ & 1.52 & 2.36 & 2.01 \\
\hline $3-$ & $\mathrm{OW}$ & 1.69 & 1.41 & 1.46 & 2.28 & 2.11 \\
\hline & JHAT & $1.89 * \# *$ & $1.59 *$ & $1.65^{*} \#$ & $2.02 * \# *$ & 2.18 \\
\hline & & $\begin{array}{r}\text { age on Pittsbu } \\
\text { Scale: } 1\end{array}$ & $\begin{array}{l}\text { gh Freshman } \\
\text { strongly disag }\end{array}$ & $\begin{array}{l}\text { agineering At } \\
e " \text { to } 5 \text { "stror }\end{array}$ & $\begin{array}{l}\text { tude Survey I } \\
\text { sly agree" }\end{array}$ & ctors \\
\hline $\begin{array}{l}\mathrm{LT} \\
\mathrm{Qu}\end{array}$ & & $\begin{array}{l}\text { Confident in } \\
\text { math and } \\
\text { science }\end{array}$ & $\begin{array}{l}\text { Confident in } \\
\text { engineering/ } \\
\text { computer } \\
\text { skills }\end{array}$ & $\begin{array}{l}\text { Confident in } \\
\text { liberal arts }\end{array}$ & $\begin{array}{l}\text { Perfer to } \\
\text { work } \\
\text { alone/not on } \\
\text { teams }\end{array}$ & \\
\hline $1-$ & $\mathrm{JHY}$ & $3.64 * *$ & $3.56^{* *}$ & $2.69++$ & $2.50+\#+$ & \\
\hline $2-$ & HAT & 3.96 & 3.80 & 2.62 & 3.18 & \\
\hline $3-$ & $\mathrm{OW}$ & 3.94 & 3.85 & 2.46 & 2.83 & \\
\hline & JHAT & 3.96 & 3.82 & $2.86^{*} \# *$ & $2.75 \# \#$ & \\
\hline * & LTM & uadrant 4 is stat & stically differen & from all other & dadrants; $\mathrm{p}<.0$ & \\
\hline$* *$ & LTM & uadrant 1 is stat & stically differen & from all other & dadrants; $\mathrm{p}<.0$ & \\
\hline \# & LTM & uadrant 4 is stat & stically differen & from quadrant & $; p<.05$ & \\
\hline \#\# & LTM & uadrant 4 is stati & tically differen & from quadrant & $p<.05$ & \\
\hline \#\#\# & LTM & uadrant 4 is stat & stically differen & from quadrant & $p<.05$ & \\
\hline *\# & LTM & uadrant 4 is stati & tically differen & from quadrant & and $1 ; \mathrm{p}<.05$ & \\
\hline *\#* & LTM & uadrant 4 is stati & tically differen & from quadrant & and $2 ; \mathrm{p}<.05$ & \\
\hline+ & LTM & uadrant 1 is stati & stically differen & from quadrant & $p<<.05$ & \\
\hline++ & LTM & uadrant 1 is stat & stically differen & from quadrant & $p<<.05$ & \\
\hline+++ & LTM & uadrant 1 is stat & stically differen & from quadrant & $p<.05$ & \\
\hline$+\#+$ & LTM & uadrant 1 is stati & stically differen & from quadrant & and $3 ; \mathrm{p}<.05$ & \\
\hline$\wedge$ & LTM & uadrant 2 is stat & stically differen & from quadrant & $\mathrm{p}<.05$ & \\
\hline$\wedge$ & All qu & drants statistical & $y$ different from & each other; $\mathrm{p}<$. & & \\
\hline
\end{tabular}

The average GPA of each student was gathered at the end of the first semester. As shown in Figure 3, the students with the WHAT learners had an average GPA of 3.3: 77\% of these students scored above a 3.0. The students with the WHY or WHAT IF subscores had the lowest average GPA, with only $46 \%$ and $45 \%$ respectively, having a GPA above a 3.0.

"Proceedings of the 2003 American Society for Engineering Education Annual Conference \& Exposition, Copyright (C) 2003, American Society for Engineering Education" 
Session 2793

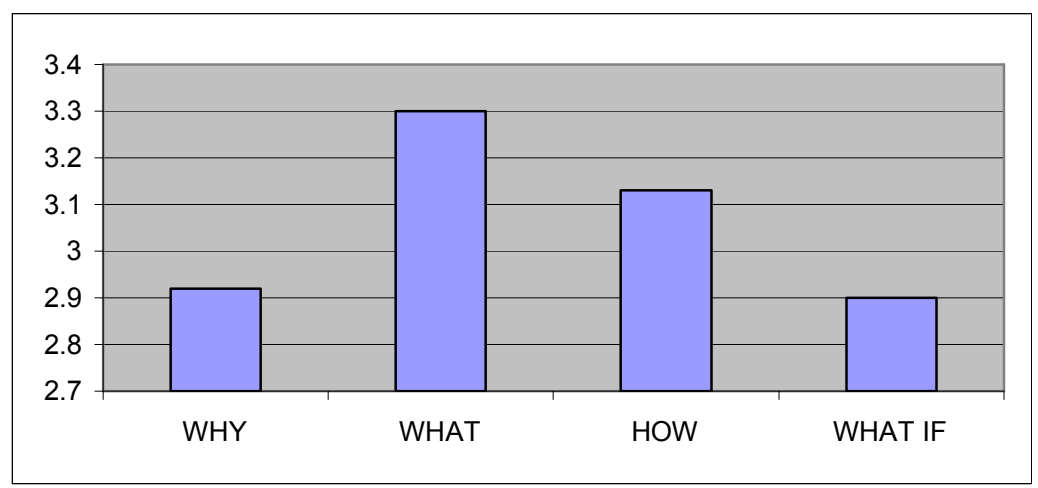

\section{Figure 3. Average GPA at End of First Semester by LTM Quadrants}

Miscellaneous observations: When asked why they chose engineering as a field of study, the majority of students responded that they liked science and math; yet an equal majority rated math and chemistry as their "most frustrating courses," over other courses (including English) in their curriculum. When asked to judge which instructional method is most frustrating to them, a majority of students chose "large lectures" over labs and smaller classes. There was a statistically significant relationship between students' perception of their writing skills and their timemanagement skills.

\section{Preliminary Conclusions}

Although the preliminary results do not, as of this writing, provide enough support for specific conclusions, some tentative observations are warranted. It is speculated that most engineers would have a LTM score which would show them higher in the WHAT and HOW subscores of the LTM. We speculate that students who have high scores on the LTM in the WHY and WHAT IF quadrants will have more difficulty in a traditional educational system that has tended to produce engineers who are WHAT and HOW types, while the engineering professions are eager to train and hire more speculative, inventive, "outside-the-box" thinkers--those who fit the profile of LTM types WHY and WHAT IF--their educational experiences are not well matched to their learning styles and preferences. As further correlations become available, it may be possible to pinpoint certain key factors affecting students' success and retention across the entire cohort of first-year students.

The original hypotheses (that traditional engineering education may be a deterrent to innovative thinkers, that students are not aware of their learning strategies, and that students who lack confidence may have more difficulty in engineering) are still being supported. More information about the relationship of the above findings to the "retention" of these students will give us insight into these hypotheses.

As soon as initial measures of success are available, as determined by grades in courses and early drop-outs, the researchers will be able to relate these measures to items and item clusters on the LTM, LASSI, Pittsburgh Inventory, and weekly surveys and journals. The results will give us a clearer picture of student success as it relates to types, styles, and habits, which can then be used

"Proceedings of the 2003 American Society for Engineering Education Annual Conference \& Exposition, Copyright (C) 2003, American Society for Engineering Education"” 
to examine teaching practices and the structure of the curriculum, and develop both facultydevelopment initiatives and student interventions to increase success and retention rates.

\section{Bibliography:}

${ }^{1}$ Seymour, E. and Hewitt, N. M. (1994). "Talking about leaving -factors contributing to the high attrition rates among science, mathematics and engineering undergraduate majors", final report to the Alfred P. Sloan Foundation on an Ethnographic Inquiry at Seven Institutions, Bureau of Sociological Research, University of Colorado, Boulder, April.

${ }^{2}$ Felder, R.M., Felder, G.N., and Dietz, E.M. (1998). "A longitudinal study of engineering student performance and retention. V.comparisons with traditionally-taught students." Journal of Engineering Education, ASEE, 87 (4) , pp. 469-480.

${ }^{3}$ Hermann, N. (1990). The Creative Brain, Brain Books, Lake Lure, NC.

${ }^{4}$ Bernold, L.E., Bingham, W.L., McDonald, P.H. and Attia, T.M. (2000). "Influence of learning type oriented teaching on academic success of engineering students," Journal. of Engineering Education, ASEE, April, pp. 191199.

${ }^{5}$ Haught, P.A., Hill, L. A., Walls, R. T., and Nardi, A. H. (1998). "Improved learning and study strategies inventory (LASSI) and academic performance: The impact of feedback on freshman." Journal Of The First-Year Experience, 10,2, pp. $25-40$.

${ }^{6}$ Besterfield-Sacre, M., Atman, C.J., and Sherman, L.J. (1997). "Characteristics of freshman engineering students: Model for determining student attrition in engineering." Journal. of Engineering Education, ASEE, April.

${ }^{7}$ Weinstein, C.E., Palmer, D.R. and Schulte, A.C. (1999). LASSI: Learning and Study Strategies Inventory, http://www.hhpublishing.com/LassiPage.html.

${ }^{8}$.Kolb, D.A. (1985). The Learning-Styles Inventory, McBer, Boston, MA.

${ }^{9}$ McCaulley M. H., Godleski, E.S., Yokomoto, C.F., Harrisberger, L. and Sloan E.D. (1983). "Applications of psychological type in engineering education.” Journal of Engineering Education, vol. 82, no. 2, pp. 394-400.

${ }^{10}$ Harb, J.N., Terry R.E., Hurt, P., and Williamson, K. (1991). Teaching Through the Cycle - Application of Learning Style Theory to Engineering Education at Brighman Young University, BYU Press, Provo, Utah.

\section{Author Biographical Information:}

JONI E. SPURLIN, Ph.D., is the Director of Assessment, College of Engineering, North Carolina State University. She has had 21 years experience in higher education and more than 12 years of experience in assessment, evaluation, and institutional research. She provides leadership and expertise to faculty and staff in development and assessment of program objectives and outcomes. She administers the website: www.engr.ncsu.edu/assessment.

"Proceedings of the 2003 American Society for Engineering Education Annual Conference \& Exposition, Copyright (C) 2003, American Society for Engineering Education” 
LEONHARD E. BERNOLD, Ph.D. is currently an associate professor, Department of Civil Engineering, College of Engineering, North Carolina State University. He is head PI for the NSF grant project: LESSONS

CATHY L. CROSSLAND, Ph.D. is currently a professor of the department of Curriculum and Instruction with the College of Education, North Carolina State University. She was responsible for developing the weekly journal questions for the project.

CHRIS M. ANSON, Ph.D. is professor of English and the Director of the Campus Writing and Speaking Program at North Carolina State University. He is a co-PI on the project and is analyzing the data in terms of impact on writing and speaking issues. 